территорий муниципальных образований. - Волгоград, 2017. - 128 с.

11. Волгоградская область в цифрах. 2015: краткий сб. / Терр. орган Фед. службы гос. статистики по Волгогоградской обл. - Волгоград: Волгоградстат, 2016. - 376 с.

Воробьев Александр Васильевич, канд. экон. наук, доизент кафедры «Землеустройство и кадастры», Волгоградский государственный аграрный университет. Россия. 400002, г. Волгоград, Университетский просп., 26. Тел.: (8442) 41-11-20.

Ключевые слова: сельскохозяйственные угодья; пашня; первичный учет земель; почвенное обследование; мониторинг земель; признаки неиспользования земельных участков; кадастровая оценка земель.

\title{
ACCOUNTING OF UNUSED ARABLE LAND, THE PROBLEMS OF ITS WITHDRAWAL FROM THE AGRICULTURAL LANDS IN THE VOLGOGRAD REGION
}

Vorobyev Aleksandr Vasylyevich, Candidate of Economic Sciences, Associate professor of the chair "Land Management and Cadastre”, Volgograd State Afgrarian University. Russia.

Keywords: agricultural lands; arable land; primary land accounting; soil survey; land monitoring; signs of non-use of land plots; cadastral evaluation of land.

Over 1.5 million hectares of arable land have not been used in the Volgograd region for many years. This is an area comparable to all arable lands in the republics of the North
Caucasus Federal district. In article the procedure of compulsory withdrawal of the parcels of land from structure of lands of agricultural purpose established by the Federal law of 24.07.2002 No. 101-FZ "about turnover of lands of agricultural purpose" is investigated. It is shown the poor state of land records management. It is concluded that the forced withdrawal of land due to the decrease in fertility and on the grounds of non-use of land in regional agricultural production will be long-term, carried out in small volumes and be local in nature.

удк 636.5.033.1.16.7.

\section{НОВАЯ КОРМОВАЯ ДОБАВКА «М-FEЕD» В РАЦИОНАХ ПЕРЕПЕЛОК-НЕСУШЕК}

\author{
ГАЙИРБЕГОВ Джунайди Шарамазанович, Национальный исследовательский Мордовский \\ государственный университет имени Н.П. Огарёва
}

ИБРАХИМ Фаркат Шауки Ибрахим, Национальный исследовательский Мордовский государственный университет имени Н.П.Огарёва

Изучено влияние кормовой добавки нового поколения «М-Fеед» на переваримость питательных веществ рациона перепелками-несушками и их яичную продуктивность. Установлено, что оптимизация количества данной добавки в рационах перепелок улучшает переваримость основных питательных веществ и увеличивает яичную продуктивность на 5,4\%.

Введение. Для нормальной жизнедеятельности организма птицы и получения полноценной продукции необходимо обеспечить их всеми питательными и биологически активными веществами. Из большого числа последних наибольшее внимание ученых и практиков привлекают сравнительно дешевые, доступные для применения, экологически чистые корма $[2,3,7,8]$ и кормовые добавки $[4,5]$. Одной из таких добавок нового поколения является «M-Feed», которая представляет собой высокотехнологичный комбинированный и абсолютно натуральный продукт, созданный в крупнейшей европейской компании OLMIX с использованием нанотехнологий $[1,4,6]$. По данным этих источников, в состав добавки входят природные неорганические и органические ингредиенты: монтмориллонит, Amadiete ${ }^{\mathrm{R}}$, инфузорная земля, прослойка дрожжей (маннанолигосахариды), экстракты морских водорослей (полисахариды) и эфирные масла.
«M-Feed»- натуральный и эффективный заменитель кормовых антибиотиков, пробиотиков и пребиотиков. Кроме того, для молодняка сельскохозяйственных животных «M-Feed» является альтернативой разным стимуляторам роста $[1,6]$. Попадая в желудочно-кишечный тракт,она начинает поглощать вредные вещества. Использование его в животноводстве снижает затраты на профилактику и лечение желудочно-кишечных расстройств.

Данные литературных источников показывают, что до настоящего времени в них отсутствуют сведения о влиянии данной кормовой добавки на организм перепелок-несушек. Поэтому изучение ее влияния на переваримость питательных веществ рациона и яичную продуктивность перепелок-несушек является актуальным и важным.

методика исследований. Научно-хозяйственный опыт проводили в условиях ветеринарной клиники Аграрного института Национального исследовательского Мордовского государс- 
твенного университета имени Н.П. Огарёва. Для опыта были отобраны четыре группы суточных перепелок маньчжурской породы, по 100 голов в каждой. Перепелок содержали в одинаковых условиях. Температурный и световой режимы, влажность воздуха, фронт кормления и поения в период опыта соответствовали рекомендуемым нормам.

Перепелкам всех групп до 3-недельного возраста давали полнорационный стартерный комбикорм, с 3-до 5-недельного возрастаростовой и с 5-недельного возраста финишный. Контрольная группа птицы получала комбикорм без добавки «M-Feed», аналогам из первой опытной группы в состав рациона ежесуточно вводили изучаемую кормовую добавку - 200 мг на 100 г комбикорма, из второй и третьей опытных групп - по 400 и 600 мг на 100 г комбикорма соответственно. На фоне научно-хозяйственного опыта на 40-е сутки был проведен балансовый опыт по методике ВИЖ. Для этого из каждой группы отобрали по 3 головы. Химический состав комбикорма и помета устанавливали по общепринятым методикам зоотехнического анализа.

Для определения яичной продуктивности из каждой группы под наблюдение были взяты по 45 голов несушек. Интенсивность яйцекладки выявляли в течение 150 дней, ежедневно с 5-6недельного возраста, учитывая количества снесенных яиц.

Результаты исследований. В ходе исследований было установлено, что добавка «M-Feed» в рацион перепелок 1-й опытной группы в количестве 200 мг/100 г комбикорма способствовала повышению переваримости сухого вещества по сравнению с контролем на 3,11 \% $(p<0,05)$, органического вещества - на 3,98 \% $(p<0,01)$, сырого протеина - на 2,16 \% ( $<<0,05)$, жира - на 3,14\% $(p<0,05)$, клетчатки - на 3,26\% $(p<0,05)$ и БЭВ на $4,567 \%(p<0,05)$, табл. 1.

Следует также отметить, что перепелки из 1-й опытной группы лучше переваривали все питательные вещества кормов рациона по сравнению с аналогами из 2-й опытной группы, получавшими в составе рациона «M-Feed» в количестве
400 мг/100 г комбикорма. Так, разница в переваримости сухого вещества рациона между 1-й и 2-й опытными группами составила $4,97 \% \quad(p>0,05)$, органического вещества $5,78 \%(p>0,05)$, сырого протеина - 1,84\% $(p>0,05)$, жира - 2,43\% $(p>0,05)$, клетчатки $2,36 \%(p>0,05)$ и БЭВ - 7,54\% $(p>0,05)$. Примерно такая же тенденция в переваримости питательных веществ наблюдалась между 1-й и 3-й опытными группами.

Сравнивая 2-ю и 3-ю опытные группы, где применяли новую кормовую добавку в составе комбикорма в количестве 400 и 600 мг/100 г, следует отметить, что лучшие показатели по переваримости сухого и органического веществ, безазотистых экстрактивных веществ имели несушки из 3-й группы, а по переваримости протеина, жира и клетчатки из 2-й.

Для оценки эффективности использования в составе комбикорма добавки «M-Feed» были проведены наблюдения и за яичной продуктивностью перепелок-несушек (табл. 2).

Использование в составе рациона перепелок-несушек разных дозировок новой кормовой добавки не оказало существенного влияния на сроки снесения первого яйца. Однако применение данной добавки в количестве 200 мг/100 г комбикорма оказало положительное действие на сроки достижения 50\%-й яйценоскости и общую яйценоскость. Так, возраст достижения 50\%-й яйценоскости в 1-й опытной группе был достигнут на 3 дня раньше, чем у сверстниц из контрольной группы, и на 1 день, чем из 2-й опытной группы.

По количеству снесенных яиц на начальную несушку перепелки из 1-й опытной группы превосходили контрольных аналогов в среднем на 6,8 шт., из 2-й группы - на 2 шт. и из 3-й группы - на 5,2 шт. За 5 месяцев наблюдений от перепелок-несушек из 1-й группы было получено яиц больше на 306 шт. (на 5,6 \%) по сравнению с контролем, на 89 шт. (на 1,5 \%) по сравнению co 2-й опытной группой и на 232 шт. (на 4 \%) по сравнению с 3-й опытной группой.

Таблица 1

Переваримость питательных веществ рациона, \%

\begin{tabular}{|l|c|c|c|c|}
\hline \multirow{2}{*}{ Питательные вещества } & \multicolumn{4}{|c|}{ Группа } \\
\cline { 1 - 5 } & контрольная & 1 -я опытная & 2-я опытная & 3 -я опытная \\
\hline Сухое вещество & $64,95 \pm 0,76$ & $68,06 \pm 0,18$ & $63,09 \pm 0,41$ & $65,81 \pm 1,22$ \\
\hline Органическое вещество & $65,98 \pm 0,63$ & $69,88 \pm 0,24$ & $64,10 \pm 0,48$ & $67,34 \pm 1,30$ \\
\hline Протеин & $42,65 \pm 0,30$ & $44,81 \pm 0,45$ & $42,97 \pm 0,12$ & $42,38 \pm 0,30$ \\
\hline Жир & $51,80 \pm 0,62$ & $54,94 \pm 0,60$ & $52,51 \pm 0,31$ & $51,69 \pm 0,29$ \\
\hline Клетчатка & $17,14 \pm 0,92$ & $20,40 \pm 0,39$ & $18,04 \pm 0,98$ & $17,46 \pm 0,56$ \\
\hline БЭВ & $77,39 \pm 0,96$ & $81,96 \pm 0,48$ & $74,42 \pm 0,62$ & $79,47 \pm 1,95$ \\
\hline
\end{tabular}


Яичная продуктивность перепелок-несушек за 150 дней яйценоскости

\begin{tabular}{|l|c|c|c|c|}
\hline \multicolumn{1}{|c|}{ Показатель } & \multicolumn{3}{c|}{ Группа } \\
\cline { 2 - 5 } & контрольная & 1-я & 2 -я & 3-я \\
\hline Количество перепелок в группе, гол. & 45 & 45 & 45 & 45 \\
\hline Снесено первое яйцо в возрасте, дней & 38 & 38 & 39 & 39 \\
\hline Снесено 50 \% яиц в возрасте, дней & 121 & 118 & 119 & 118 \\
\hline $\begin{array}{l}\text { Количество полученных яиц в расчете } \\
\text { на начальную несушку, шт. }\end{array}$ & 125,7 & 132,5 & 130,5 & 127,3 \\
\hline Снесено всего яиц, шт. & 5657 & 5963 & 5874 & 5731 \\
\hline Снесено всего яиц в среднем за месяц, шт. & 1131,4 & 1192,6 & 1174,8 & 1146,2 \\
\hline 土от контрольной группы & - & +306 & +217 & +74 \\
\hline Процент к контролю & 100 & 105,4 & 103,8 & 101,3 \\
\hline
\end{tabular}

Следует также отметить, что несушки, получавшие «M-Feed» в количестве 400 и 600 мг 100 г комбикорма, по общему количеству снесенных яиц превосходили контроль на 217 и 74 шт., или на 3,8 и $1,3 \%$ соответственно.

Заключение. Добавка в рационы перепелокнесушек, в состав комбикорма, новой кормовой добавки «M-Feed» в оптимальном количестве (200 мг/100 г комбикорма) оказывает положительное действие на переваримость в их организме основных питательных веществ. Кроме того, «M-Feed» способствует увеличению их яичной продуктивности на 5,4 \% по сравнению со сверстницами из контрольной группы, не получавшими данную добавку.

\section{СПИСОК ЛИТЕРАТУРЫ}

1. Адучиев Б.К., Арылов Ю.Н. Влияние новой кормовой добавки «M-Feed» на мясную продуктивность и качество мяса баранчиков калмыцкой курдючной породы // Овцы, козы и шерстяное дело. - 2015. № 2. - C. 34-37.

2. Влияние гидропонного зеленого корма на переваримость питательных веществ и обмен азота, кальция и фосфора в организме кур-несушек кросса Хайсекс коричневый / А.А. Васильев [и др.]// Современные способы повышения продуктивных качеств сельскохозяйственных животных, птицы и рыбы в свете импортозамещения и обеспечения продовольственной безопасности страны: материалы Междунар. науч.-практ. конф., посвящ. 85-летию со дня рождения д-ра с.-х. наук, Почетного работника ВПО РФ, профессора кафедры «Кормление, зоогигиена и аквакультура» Коробова А.П.; СГАУ им. Н.И. Вавилова. - Саратов, 2015. - С. 202-206.
3. Гидропонный зеленый корм в рационах несушек / А.А. Васильев [и др.] // Животноводство России. - 2017. - № 7. - С. 13-17.

4. Кормовая добавка природного происхождения в рационах перепёлок / Ф.Ш. Ибрахим [и др.] // Птицеводство. - 2017. - № 7. - С. 29-31.

5. Коробов А.П., Кочнев Ю.А. Использование биологически активных веществ в кормлении свиней и птицы. - Саратов: Науч. кн., 2008. - 386 с.

6. Применение натурального стимулятора роста «M-Feed» в промышленном птицеводстве / И.А. Егоров [и др.]. - СПб., 2010. - С. 12-22.

7. Эффективность использования гидропонного зеленого корма в рационах кур-несушек / А.А. Васильев [и др.]// Аграрный научный журнал. 2015. - № 1. - C. 14-17.

8. Эффективность использования гидропонного зеленого корма в рационах кур-несушек / Л.А. Сивохина [и др.] // Аграрная наука в XXI веке: проблемы и перспективы: материалы VIII Всерос. науч.-практ. конф. - Саратов, 2014. - С. 275-278.

Гайирбегов Джунайди Шарамазанович, $\partial-p$ c.- $x$. наук, проф. кафедры зоотехнии им. профессора С.А.Лапшина, Национальный исследовательский Мордовский государственный университет имени Н.П. Огарёва. Россия.

Ибрахим Фаркат Шауки Ибрахим, аспирант кафедры зоотехнии им. профессора С.А. Лапшина, Национальный исследовательский Мордовский государственный университет имени Н.П. Огарёва. Россия.

430904, г. Саранск, p.n. Ялга, ул. Российская, 31.

Тел.: (8342) 25-41-65; e-mail: kafedra_zoo@mail.ru.

ключевые слова: перепелки-несушки; кормление; добавка «M-Fеed»; переваримость; питательные вещества; продуктивность.

\section{NEW FEED ADDITIVE “M-FEED” IN RATION OF QUAIL LAYERS}

Gayirbegov Djunaidi Sharamazanovish, Doctor of Agricultural Sciences, Professor of the chair "Zootechnics named after Professor S.A. Lapshin", National Research Mordovia State University named after N.P. Ogarev. Russia.

Ibrahim Farqad Shawqi Ibrahim, Post-graduate Student of the of the chair "Zo-otechnics named after Professor S.A. Lapshin", National Research Mordovia State University named after N.P. Ogarev. Russia.
Keywords: quail; feeding; additive; digestibility; nutrients; productivity.

It has been studied the effect of fodder additives of new generation "M-feed" on di-gestibility of nutrient by quail layers and their egg production. It is found out that the optimization of the amount of the additive in rations of quails improves the digestibility of the main nutrients and increases their egg production by 5.4\%. 